INSTITUTE OF FORESTRY • BELGRADE

INSTITUT ZA ŠUMARSTVO • BEOGRAD

SUSTAINABLE FORESTRY

COLLECTION 69-70, 2014
ODRŽIVO ŠUMARSTVO

ZBORNIK RADOVA 69-70, 2014

UDK $630 * 181.45+630 * 424.5: 546.47(497.11$ Beograd $)=111$

Original scientific paper

\title{
THE STUDIES OF ZINC (Zn) CONCENTRATIONS IN WOODY AND HERBACEOUS PLANTS IN THE REGION OF BELGRADE
}

\author{
Dragica STANKOVIĆ ${ }^{1}$, Dragica VILOTIĆl ,Vladan IVETIĆ ${ }^{1}$, Djordje JOVIĆ \\ Dušan JOKANOVIĆ ${ }^{l}$, Jovana DEVETAKOVIĆ' ${ }^{l}$
}

\begin{abstract}
These studies are aimed at the determination of load of the plant ecosystems with the heavy metal ( $\mathrm{Zn})$ and the accumulation of it in this area, so that based on the results, if necessary, the appropriate protection measures of this higly-valued area can be appplied. The woody species lime tree and Austrian pine at the plots 1 and 2 in these studies show deficiency or are on the verge of the deficiency. Based on the results, heavy metal zinc is not the adverse factor in the natural protected area "Avala".
\end{abstract}

Key words: Woody species, herbaceous species, Avala, level, zinc.

\section{ISTRAŽIVANJA KONCENTRACIJE CINKA (ZN) U DRVENASTIM I ZELJASTIM BILJKAMA NA PODRUČJU BEOGRADA}

Izvod: Cilj ovih istraživanja usmeren je na to da se ustanovi opterećenost ekosistema biljaka teškim metalom (Zn) i njihova akumulacija na ovom području, kako bi se na osnovu dobijenih rezultata, ako je potrebno, mogle blagovremeno preduzeti odgovarajuće mere zaštite ovog visokovrednog područja. Drvenaste vrste lipa i crni bor na lokalitetu 1. i na lokalitetu 2. u ovim istraživanjima pokazuju deficit ili su na samoj granici deficita. Na osnovu svih dobijenih rezultata teški metal Cink ne predstavlja ugrožavajući činilac na području zaštićenog prirodnog dobra „Avala“.

Ključne reči: Drvenaste vrste, zeljaste vrste, Avala, koncentracija, cink.

\footnotetext{
${ }^{1}$ Faculty of Forestry, the University of Belgrade, Kneza Višeslava 1, Belgrade, Serbia (dragica.stankovic@sfb.bg.ac.rs; vladan.ivetic@sfb.bg.ac.rs; dusan.jokanovic@sfb.bg.ac.rs; jovana.devetakovic@sfb.bg.ac.rs;)

${ }^{2}$ Institute of Forestry, - Belgrade Kneza Viseslava 3,Belgrade, Serbia (jovicdjm@yahoo.com) Translation: Marija Stojanović
} 


\section{INTRODUCTION}

It is generally known, and scientifically proved, that the greenery of a contemporary town or city is its integral part which is mainly associated to human health. Based on the above claims, it is needed to point to the necessity of the permanent monitoring of the level of heavy metals in plants, as the indicators of the environmental pollution, which can have adverse effects, not only on the forest ecosystems, but on man, also.

Avala is the mountain situated about 17 kilometers southeast of Belgrade, on the road to Kragujevac. It is the northernmost mountain of the Šumadija Mountain Range and is classified as the low island mountain.

Based on the special forest management (2008-2017), the natural protected area "Avala", covering an area of 489.13 hectares, is located at the territory of the city of Belgrade, in the city municipality Voždovac, 15 kilometers south of the centre of the city. The total area of 74.35 hectares $(15.2 \%)$ is privately-owned, and 414.8 hectares $(84.8 \%)$ refer to the other types of ownership. The agricultural land accounts for $19.9 \%$ of the total natural protected area "Avala". The area of forests aimed at the land protection is 363.62 hectares $(75 \%$ of the total natural protected area "Avala"), out of which $68 \%$ are of the coppice origin, and $32 \%$ of artificial origin.

Heavy metals can be found in all environmental media, as the results of different types of human acvities. The origin of the heavy metals in fine particles in the air is double: natural and anthropogenic. There is not sufficient knowledge on their distribution in nature and role in pollution. It is partially known that the emission souces, by the following processes: turbulent diffusion, dry and wet deposition, then by the migration via soil and water, participate in the circulation through the nature, thereby disturbing the natural balance of these elements, which is of the particular significance to the biosphere.

Similarly to other metals, zinc also participate in the activity of enzymes, the most important of which is carboanhidrase (Ohki, 1976) (Aliev, Guliev,1990). Zinc is the necessary component of RNA-polymerase and participates in the synthesis of auxins (Kastori, 1990, Kastori et all, 1993). Heavy metals are constantly absorbed by the plants during the growing season and throughout the year, achieving, as a rule, the highest level by the end of the growing season. (Krstić, et all 2008, Stanković et al, 2011, 2013 ).

The high level of $\mathrm{Zn}$, as well as of other heavy metals, has toxic effect in plants. The excess od this elements in plants rarely occurs in nature. The resistance of some plants to the excess of this element is different. Along with the series of physiological disturbances, owning to the lack of zinc, some plant diseases, such as leaf chlorosis, abnormal cell growth, etc, occur (Stanković et al, 2009). The typical symptoms of the lack of zinc in plants are the occurrence of rose rosette and littleleaf diseases. The excess of zinc can be toxic, and in the sufficient quantity it increases the resistance to some diseases (phytophtora). 


\section{MATERIAL AND METHOD}

Having in mind the importance of the quality of environment in the domains aimed at the recreation, the studies regarding the concentration of heavy metals in plant leaves in Avala were conducted.

Three plots in the Avala area of the outstanding features, out of which the samples for the analysis were taken, were selected.

The selected plots, based on the special forest management for Forest Unit "Avala" (2008 - 2017) for Forest Unit "Avala" in the following way:

Plot 1 - on the ascending road in the area of outstanding features "Avala"

Plot 2 - on the top of Avala (near the tower)

Plot 3 - on the descending road (Stari Majdan)

Plot 4 - Control - Bulevar Despota Stefana Street in the centre of Belgrade

Upon the survey of several potential plots, the fourth one, so-called "control" plot in the centre of Belgrade in Bulevar Despota Stefana Street, where the traffic is very frequent, was selected.

During the selection of plants for analysis, the inventory of all plant species in this area was accurately conducted. And for these analyses the following plant species were selected:

1. Tillia tomentosa Mnch.- Silver lime

2. Pinus nigra Arn.- Austrian pine

3. Plantago media L.- Hoary plantain

4. Taraxacum officinale Web.- Dandelion

Starting exactly from the fact that the amount of heavy metals in plants directly depend on the distance from the road, the plants were taken at each plot 200-300 meters long, at the depths up to 15 meters. Only the leaves of the plants were sampled. The samples of the leaves were collected and for each species 1-2 kilograms of material were collected from each plot. The samples were dried without the prior washing so that the dry matter was gained. The dry leaves were then dried in the hothouses at $105^{\circ} \mathrm{C}$, grinded and used for the laboratory analyses. (Maksimović et all. 2002):

The content of the heavy metal zinc was determined by using the method of atomic absorption spectrometry, by "Thermo series M" mashine.

The obtained data were processed statistically by using the method of the analysis of variance, by LSD - test. The significance of the mean values was tested by using the Duncan's test. All tests were done at the significance level $p \leq 0.05$. The levels (average values) in the figures marked by the same letters did not differ significantly at the significance level $p=0.05$. The results were presented in the appropriate graphical way.

The analyses were done in the laboratory of the Department of Biology and Ecology of the Faculty of Natural Science and Mathematics in Novi Sad and the Institute for Biological Research "Siniša Stanković" in Belgrade. 


\section{RESULTS AND DISCUSSION}

Zinc is one of the micronutrients which are very important to the normal life processes in plants and is needed in very small amounts of the order of magnitude $\mu \mathrm{g}$ or ppm (parts per million).

The concentration of zinc in the soil ranges from $10-300 \mathrm{ppm}$ and is found in the form $\mathrm{Zn} 2+$ ions. The concentration of zinc in the plants is very small (20 to $200 \mathrm{ppm}$ ). The level lower than $20 \mathrm{ppm}$ in the dry matter is critical value for most of the plant species (Carroll, Loneragan, 1969). The resistance of some plants to the excess of this element is different, and the symptoms occur when the amount of it in dry matter ranges from 100 to $300 \mu \mathrm{g} \mathrm{Zn} \mathrm{g-1.} \mathrm{Having} \mathrm{in} \mathrm{mind} \mathrm{the}$ importance of zinc in plant nutrition, considerably greater attention of the world researchers was paid to the lack, than to the excess of it. By the single analysis of variance it was studied if there were statistically significant differences in the mean values of the amount of zinc in all plant species at each observed plot. Since by using the analysis of variance $\mathrm{P}=0.0000<0.05$ was gained, it can be claimed that, at the probability level $95 \%$, there are are statistically significant differences in the amount of $\mathrm{Zn}$ in the observed plant species at all observed plots.

By using Dancan's test it was studied whether there were statistically significant differences (at the probability level 95\%) among the mean values of $\mathrm{Zn}$ amounts at the splant species at each of the sites.

At the ascending road towards the area of the outstanding features "Avala", although, generally speaking, there are the statistical differences among the mean values of zinc amounts, based on the results of Dancan's test, it can be claimed that the lime tree and Austrian pines are the homogenous group (i.e. there are no statistically significant differences among the mean values of the amount of zinc between them), and that the mean values of the amount of zinc in hoary plantain and dandelion are statistically significantly different, regarding the differences between them and regarding all other species. (Figure 1).

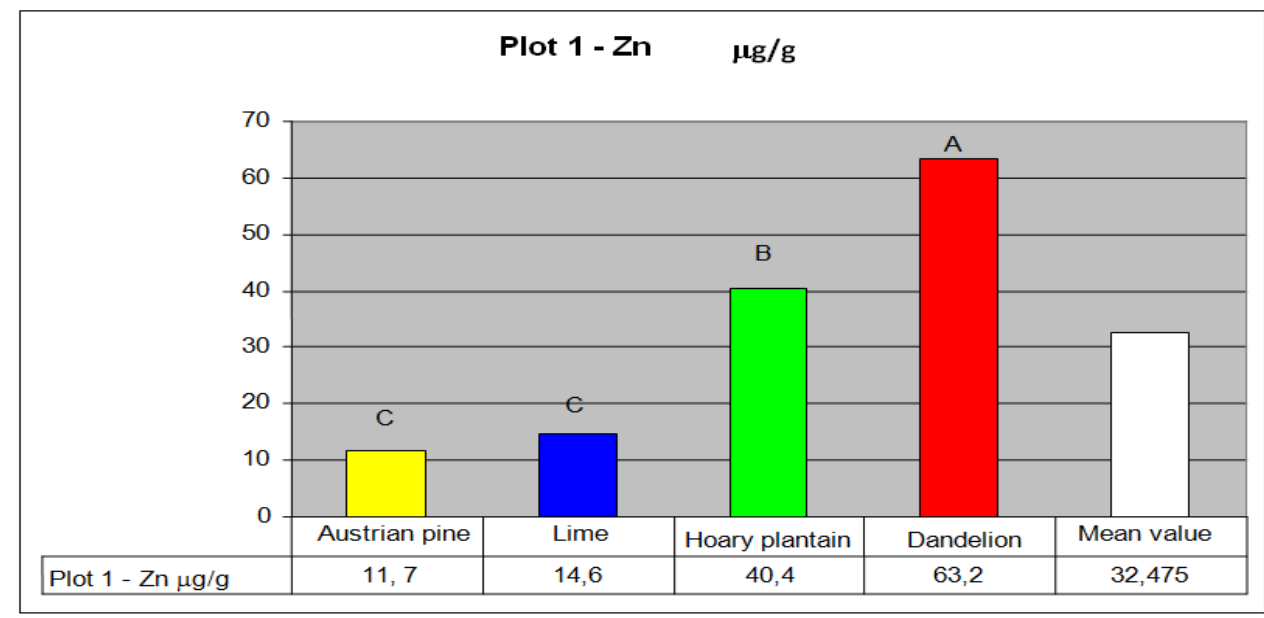

Figure 1 The amount of zinc in the observed plant species at the site 1 


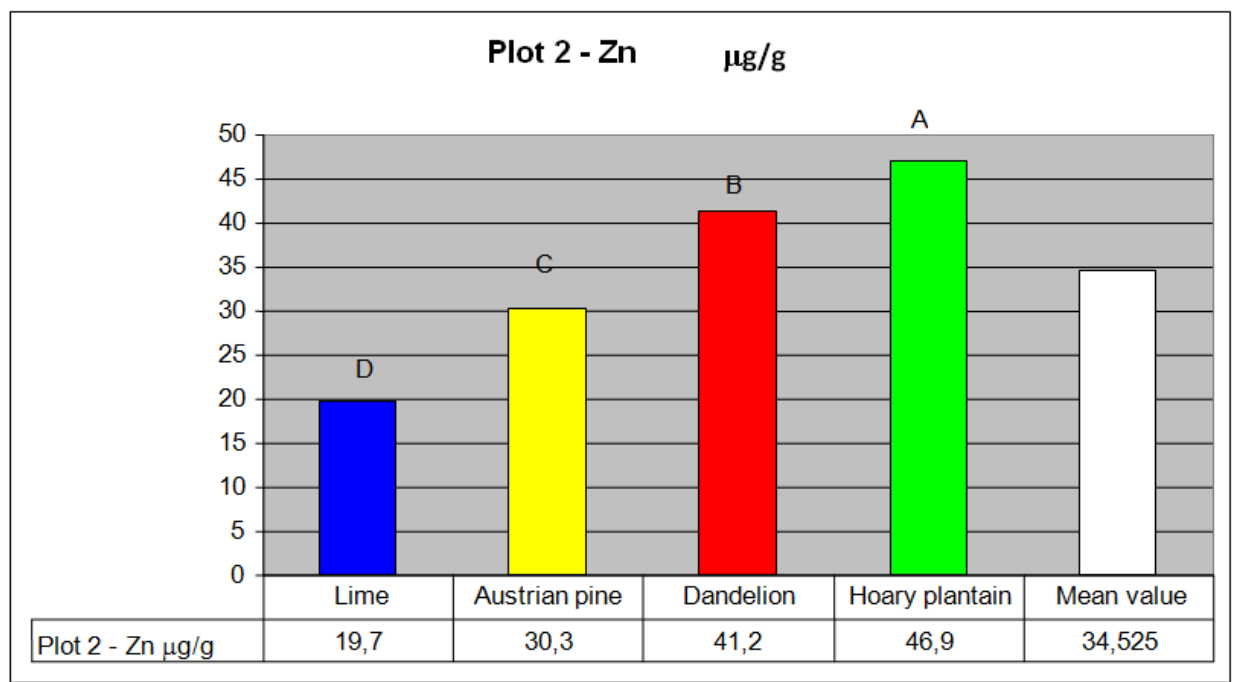

Figure 2 The amount of zinc in the observed plant species at the plot 2

Regarding the plant species at the site 2, on the top of Avala, Dancan's test showed that the mean values of the amount of zinc in all observed plant species were statistically significantly different (Figure 2 ).

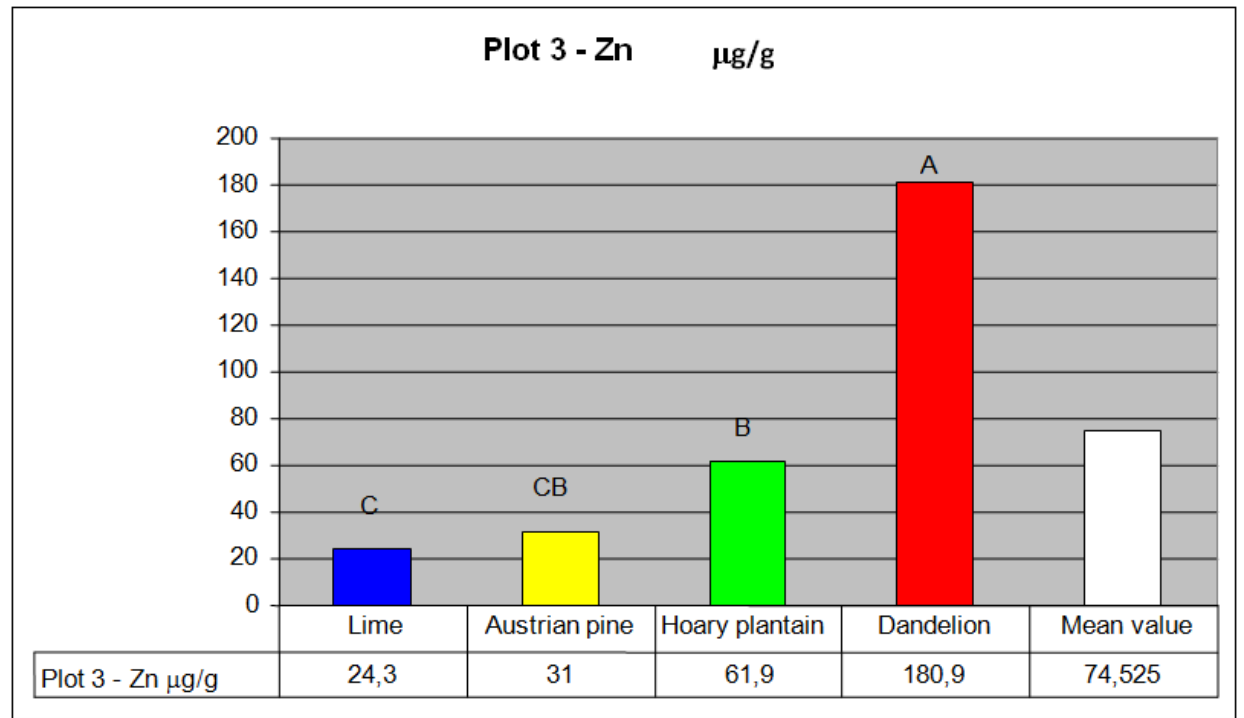

Figure 3 The amount of zinc in the observed plant species at the plot 3

At the plot located at the descending road (Stari Majdan), although generally speaking there are statistically significant differences, based on Dancan's test it can be claimed that the lime tree and Austrian pine, Austrian pine and hoary plantain are the homogenous group (i.e. there are no statistically significant diffrences between the mean values of the amount of zinc), and that the mean value of the amount of zinc in the dandelion is statistically significantly different from all other species (Figure 3). 


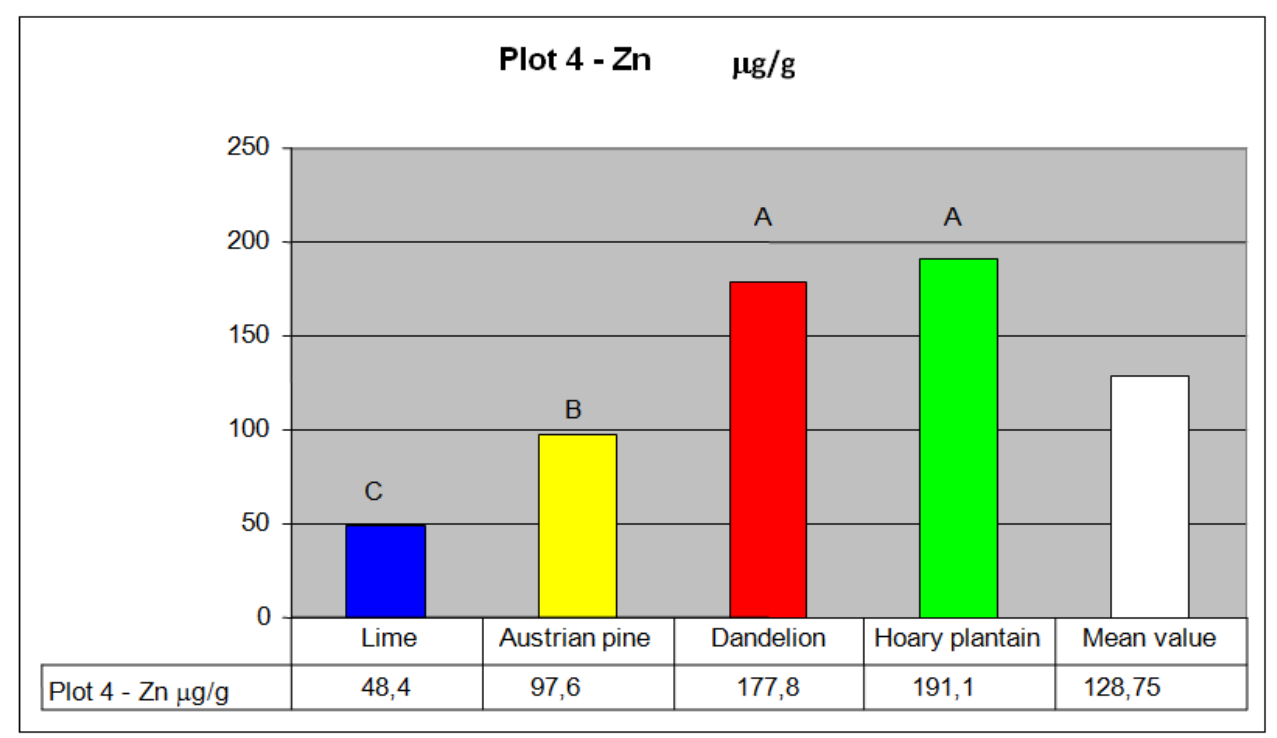

Figure 4 The amount of zinc in the observed plant species at the plot 4

At the plot in the Bulevar Despota Stefana Street in the centre of Belgrade, as well at the above plots there are statistically significant differences between the mean values of the amount of Zn. However, based on Dancan's test it is clearly visible that the dandelion and hoary plantain are the homogenous group (i.e. there are no statistically significant difference between them in the mean values of the amount of zinc), and that the mean values of the amount of zinc in the lime tree and Austrian pine are statistically significantly different regarding the differences between them and regarding all other species (Figure 4).

\section{CONCLUSION}

By comparing the data obtained in these studies with the ones from the references (Figures 1-4), it is visible that the herbaceous species dandelion and hoary plantain absorb more zinc than the observed woody plant species. The woody species lime tree $(14.6 \mu \mathrm{g} / \mathrm{g})$ at the plot 1 and Austrian pine $(11.7 \mu \mathrm{g} / \mathrm{g})$ at the plot 2 in these studies show the deficiency or are on the very verge on the deficiency. (Figures 1 and 2). By comparing the mean values in all observed plant species on each plot, it is visible that the highest accumulation of zinc was reported at the plot 4 , with the value 128,75 , and the lowest mean value was $32.47 \mu \mathrm{g} / \mathrm{g}$ at plot 1 .

The results which were obtained undoubtedly show that the samples of plant material from all plots were not contaminated by zinc, and that the lack of zinc in the plant was reported at some plots. It is important to note that zinc is not the adverse factor in the observed area of Avala.

\section{Note}

This paper was made within the projects "Forest plantations aimed at increasing the forest area in Serbia" (TR 31041) and "Ecoremediation of the degraded area 
by the production of agro-energy crops" (TR 31078) financed by the Ministry of Education and Science of the Republic of Serbia within the program aimed at the technological development for the period 2011-2014.

\section{REFERENCES}

Aliev, D.A., Guliev, N. M. (1990): Karboangidraza rasteniй. Nauka, Moscow

Carol, M.D., Loneragan J. F. (1969): Response of Plant Species to Concentration of Zinc in Solution. II Rate of Zinc Absorption and Their Relation to Growth. Austrl. J. Agric. Res. 20, 457-163.

Kastori, R. (1990): Necessary Micronutrients: Physiological Role and Importance in the Plant Protection. Scientific Book, Belgrade

Kastori, R., Petrović, N.(1993): Influence of Heavy Metals on Plants. Heavy Metals and Pesticides on Plants. Faculty of Agriculture, Novi Sad, 55-73.

Krstić, B., Stanković, D., Nikolić, N. 2008: Effect of Traffic on the Concentrations OF Phs in NP "Fruška Gora" Journal of "Biotechnology \& Biotechnological Equipment" Sofia, Bulgaria.

Krstić, B. Oljača, R., \& Stanković, D., 2011: Physiology of Woody Plants. University of Banja Luka, Faculty of Forestry (Physiology of Woody Plants. The University in Banja Luka, Faculty of Forestry), Banja Luka, p. 352.

Maksimović, I., Pajević, S. (2002): Practic Book from the Plant Physiology. Verzal, Novi Sad.

Ohki, K. (1976): Effect of Zinc Nutrition in Photosynthesis and Carbonic Anhydrase Activity in Cotton. Physiol. Planr. 38, 300-304.

Special Forest Management (2008- 2017) for Forest Management Unit "Avala". Faculty of Forestry. Belgrade

Stanković, D., Krstić, B., Igić, R., Trivan, G., Petrović, N. \& Jović, Dj., 2011. Concentration of Pollutants in the Air, Soil and Plants in the Area of National Park "Fruska gora" - Serbia. Fresenius Environmental Bulletin, Psp.Germany.- Psp. 20, 1, 44-50.

Stanković Dragica ,Medarević Milan, Krstić Borivoj, Bjelanović Ivan ., Šljukić Biljana., Karić Dušica ., Janić Milorad (2013): Concentration of Heavy Metals and Stand State of Sessile Oak (Quercus petraea (Matt.) Liebl.) in Avala Mountain (SERBIA) Carpathian Journal of Earth and Environmental Sciences, August 2013, Vol. 8, No. 3, p. 59-66.

Stanković, D., Šijačić-Nikolić, M., Krstić, B. \& Vilotić,V., 2009. Heavy Metals in the Leaves of Tree Species Paulownia elongata S.Y.Hu in the Region of the City of Belgrade. Biotechnology \& Biotechnological Equipment, Diagnosis, 23, 3, 1330-1336. 